\title{
The Influence Of Belief, Expectation, And Perception On Husband Participation In Vasectomy In Sekip Village, Lubuk Pakam Subdistrict, Deli Serdang
}

\author{
Namora Lumongga Lubis, Basyariah Lubis
}

\author{
Public Health Faculty1 \\ Universitas Sumatera Utara1 \\ Institute of Health Science Medistra2 \\ Medan1,Lubuk Pakam2 \\ Indonesia \\ namoralubis041072@gmail.com
}

\begin{abstract}
Population program, especially the reproductive rights and health including Family Planning,commencing 2005 has explicitly included as a new target in the MDGs. This is related to the4th This analytical survey study with crosssectional approach was conducted from January to June 2012 at Sekip Village, Lubuk Pakam Subdistrict, Deli Serdang District. The data obtained were analyzed through univariate analysis, bivariate analysis with Chi-square test, and multivariate analysis with multiple logistic regression tests. Increasing men's participation in Family Planning and reproductive health is an appropriate step in an attempt to encourage gender equality, but the main problem we are currently facing is the low participation of men in the implementation of Family Planning and reproductive health programs. There are many factors causing the low participation of men in Family Planning program. One of them is psychological factor such as belief, expectation and perception. The result of this study showed that belief, expectation and perception had a significant influence with sig. $=0.017,0.07$ and 0,464 . It is suggested to motivate the husbands living at Sekip Village, Lubuk Pakam Subdistrict, Deli Serdang District to participate in the vasectomy program. The Family Planning Field Workers are expected to help monitor and encourage the husbands who have performed vasectomy to be the motivators for the husbands who have not performed vasectomy.
\end{abstract}

Keywords: Belief, Perception, Expectation, Vasectomy

\section{INTRODUCTION}

Nowadays, goverment of Indonesia has started implement gender equality oriented development, but the main problem is a low participation from male to doing family planning and health reproduction programs. Even though male participation in this program is a preventive methods to prevent maternal mortality. There is 50 million. man in all over the world who using vasectomy as contraception. In Islam majority country such a Pakistan in 1998 had 5,2\% male who did vasectomy, Bangladesh $13,9 \%$ in 1997 , Malaysia 16,8 \% in 1998 whileIndonesia is the lowest vasectomy user that is $0,4 \%$. (BKKBN, 2007)

According to Sekip Village Deli Serdang district woman empowerment board in 2011, male participation on family planning is still low; using condoms $14,2 \%$, vasectomy/(MOP) 1,07\%. All this datas taken from 13 village in Lubuk Pakam district, Deli Serdang. (Data Pemberdayaan Perempuan, Anak dan Keluarga Berencana Deli Serdang, 2011)

Based on preliminary survey on Februari in Lubuk Pakam district office there are 14 people from total 830 couple of 
reproductive age who did vasectomy. It means theres only $1,6 \%$ husband did vasectomy. This number is very far from goverment targets about $4,5 \%$. It happened because of perception from male who thinks family program could decrease their virility. (Pramesti, 2012) This perception is strong enough to influence the use of family planning program and gender inequality in family planning. It showed male role on family planning is not quite optimized. (Anggraeni, 2007)

Male often imagine there will be a scar that will give a bad impact in their reproductive area after doing vasectomy. (BKKBN, 2008) Anotherrumor about vasectomy is perception of male who thinks vasectomy is a same thing with castrated. This rumor also give a big influence of husband participation in vasectomy. (Everett, 2008)Based on this problem, reseacher is interest to make a research about the influence of belief, expectation and perception on husband participation in vasectomy in Sekip Village, Lubuk Pakam District, Deli Serdang.

\section{RESEACRCH METHODS}

This is an analytical survey study with cross sectional approach was conducted from January to June 2012 at Sekip Village,
Lubuk Pakam Subdistrict, Deli Serdang. The population is all men from couple of reproductive age listed in Sekip Village about 623 people. Sample is taken with purposive sampling about 86 respondent and analyze using bivariate analysis with Chi-Square test and multivariate analysis with multiplelogistic regression test.

\section{RESULT AND ANALYSIS}

\section{Respondent Characteristics Distribution}

Sample size in this sudy are 86 people. Majority of sample are senior high school graduated 31 people (36\%). Based on religion characteristics, majority of respondent are Islam 83 people (96,5\%), based on number of children, majority of sample have more than three children 45 people $(52,3 \%)$ and based on ooccupation majority of sample are freelance 42 people. Based on belief variable there are 60 husband $(69,8 \%)$ who had good belief participated in vasectomy. Based on expectation variables there are 61 husband $(70,9 \%)$ who had good expectation participated in vasectomy and there are 70 husband $(81,4 \%)$ who had good perception about vasectomy as reproduction controller.

Table 1. Characteristic Respondent Distributions

\begin{tabular}{|l|l|l|}
\hline $\begin{array}{l}\text { Respondent } \\
\text { Characteristics }\end{array}$ & N & $\%$ \\
\hline Education & 24 & 27,9 \\
\hline Elementary & 20 & 23,3 \\
\hline Junior high School & 20 \\
\hline Senior High School & 31 & 36,0 \\
\hline Diploma & 6 & 7,0 \\
\hline Bachelor & 5 & 5,8 \\
\hline
\end{tabular}


Table 1, cont.

\begin{tabular}{|c|c|c|}
\hline \multicolumn{3}{|l|}{ Religion } \\
\hline Islam & 83 & 96,5 \\
\hline Protestant & 3 & 3,5 \\
\hline \multicolumn{3}{|c|}{ Number of Children } \\
\hline$>3$ & 45 & 52,3 \\
\hline$<3$ & 41 & 47,7 \\
\hline \multicolumn{3}{|l|}{ Occupation } \\
\hline $\begin{array}{l}\text { Goverment } \\
\text { Employess }\end{array}$ & 4 & 4,7 \\
\hline Farmer & 28 & 32,5 \\
\hline Enterpreneur & 12 & 14,0 \\
\hline Freelance & 42 & 48,8 \\
\hline \multicolumn{3}{|l|}{ Belief } \\
\hline Not good $(<5)$ & 26 & 30,2 \\
\hline $\operatorname{good}(>=5)$ & 60 & 69,8 \\
\hline \multicolumn{3}{|l|}{ Expectation } \\
\hline Not good $(<2)$ & 25 & 29,1 \\
\hline $\operatorname{good}(>=2)$ & 61 & 70,9 \\
\hline \multicolumn{3}{|l|}{ Perception } \\
\hline Not good $(<6)$ & 16 & 18,6 \\
\hline Good $(>=6)$ & 70 & 81,4 \\
\hline \multicolumn{3}{|l|}{$\begin{array}{l}\text { Vasectomy } \\
\text { Pasrticipation }\end{array}$} \\
\hline Unparticipated & 55 & 64,0 \\
\hline Participated & 31 & 36,0 \\
\hline
\end{tabular}




\section{The Correlation of Belief, Expectation andPerception on Husband It was analyzed by using Chi- Square test with $95 \%$ level of confidence $(\alpha=0.05)$.}

Table 2. The Correlation of Belief on Husband Participation

\begin{tabular}{|c|c|c|c|c|c|c|c|}
\hline \multirow{3}{*}{$\begin{array}{l}\text { Respondent } \\
\text { Expectation }\end{array}$} & \multicolumn{4}{|c|}{$\begin{array}{l}\text { Vasectomy } \\
\text { Participation }\end{array}$} & \multirow{2}{*}{\multicolumn{2}{|c|}{ Total }} & \multirow[t]{3}{*}{$\mathrm{P}$} \\
\hline & \multicolumn{2}{|l|}{ No } & \multicolumn{2}{|c|}{ Yes } & & & \\
\hline & $\mathrm{n}$ & $\%$ & $\mathrm{n}$ & $\%$ & $n$ & $\%$ & \\
\hline Not Good & 10 & 40,0 & 15 & 60,0 & 25 & 100 & 0,007 \\
\hline Good & 45 & 73,8 & 16 & 26,2 & 61 & 100 & \\
\hline Total & 55 & 64,0 & 31 & 36,0 & 86 & 100 & \\
\hline
\end{tabular}

Table 3. The Correlation of Expetation of Respondent on Husband Participation in Vasektomi

\begin{tabular}{|l|l|l|l|l|l|l|l|}
\hline \multirow{2}{*}{$\begin{array}{l}\text { Respondent } \\
\text { Belief }\end{array}$} & \multicolumn{3}{|l|}{ Vasectomy } & \multicolumn{2}{l|}{ Total } & \multirow{2}{*}{ Participation } \\
\cline { 2 - 7 } & $\begin{array}{l}\text { Not } \\
\text { Participated }\end{array}$ & \multicolumn{2}{|l|}{ Participated } & \multicolumn{2}{|l|}{} & \\
\cline { 2 - 7 } & $\mathrm{N}$ & $\%$ & $\mathrm{~N}$ & $\%$ & $\mathrm{n}$ & $\%$ & \\
\hline Not Good & 22 & 84,6 & 4 & 15,4 & 26 & 100 & 0,017 \\
\hline Good & 33 & 55,0 & 27 & 45,0 & 60 & 100 & \\
\hline Total & 55 & 64,0 & 31 & 36,0 & 86 & 100 & \\
\hline
\end{tabular}

Based on Chi-Square test using $\alpha=$ 0,05 and obtained p-value 0,017 showed there's a significant correlation between belief and husband participation with vasectomy.From table above, there are 60 respondent who had good belief which 33 respondent $(55,0 \%)$ not participated in vasectomy and 27 respondent $(45,0 \%)$ participated in vasectomy meanwhile there are 26 respondent with not good belief 
which 22 respondent not participated in vasectomy and 4 respondent $(15,4 \%)$ participated in vasectomy. Belief have a big role in decision making progress. Some people have a belief that having many childrens will brings a lucky life and full of happines. It's a old belief from long time ago.

Based on Chi-Square testwith using $\alpha$ $=0,05$ and obtained p-value $=0,007$ it showed there's a significant correlation of expectation of respondent with respondent in vasectomy.

From table 3, it showed there are 61 respondent with good expectation which 45 respondent $(73,8 \%)$ not participated in vasectomy and 16 respondent $(26,2 \%)$ participated in vasectomy. Meanwhile there are 25 respondent with not good expectation which 10 respondent $(40,0 \%)$ not participated in vasectomy and 15 respondent $(60,0 \%)$ participated in vasectomy.
Based on those result, it explain how expectation made a correlation with vasectomy participation. High economic burden in self and family living cost made a decision to participated in vasectomy as reproduction controller. They choose to participated in reproduction control program (KB) because several factor such as economic burden, uncleared income, their uncleared job as a freelance $(48,8 \%)$ is another factor that makes them to get in. It also happened in several mothers in Lubuk Pakam who participated in reproduction control program. It can be assumed, how expectation (hope) have a significant correlation on husband participation in vasectomy.

Another study showed accseptor of vasectomy usually choose this contraseption because of health reason, economic burden reason and chance to more educate children. (LDUIPULDU BKKBN, 1998)

Table 4. Correlation of Respondent Perception on Husband Participation in Vasektomi

\begin{tabular}{|c|c|c|c|c|c|c|c|}
\hline \multirow{3}{*}{$\begin{array}{l}\text { Respondent } \\
\text { Perception }\end{array}$} & \multicolumn{4}{|c|}{$\begin{array}{l}\text { Vasectomy } \\
\text { Participation }\end{array}$} & \multirow{2}{*}{\multicolumn{2}{|c|}{ Total }} & \multirow[t]{3}{*}{$P$} \\
\hline & \multicolumn{2}{|c|}{ No } & \multicolumn{2}{|c|}{ Yes } & & & \\
\hline & $\mathrm{n}$ & $\%$ & $\mathrm{~N}$ & $\%$ & $\mathrm{n}$ & $\%$ & \\
\hline Not Good & 12 & 75,0 & 4 & 25,0 & 19 & 100 & 0,464 \\
\hline Good & 43 & 61,4 & 27 & 38,6 & 53 & 100 & \\
\hline Total & 55 & 64,0 & 31 & 36,0 & 86 & 100 & \\
\hline
\end{tabular}

Based on Chi-Square testusing $\alpha=$ 0,05 and obtained $p$-value $=0,464$ it showed there's no correlation between perception with husband participation in this study. From table 4, it showed based on perceptiom there are 70 respondent with good perception which 43 respondent $(61,4$ $\%$ ) not participated in vasectomy and 27 respondent (38,6 \%) participated in vasektomi meanwhile 16 respondent who had not good perception, which 12 respondent $(75,0 \%)$ not participated and 4 respondent $(25,0 \%)$ participated in vasectomy. From these result it can be explained how perception didnt have correlation on husband participation because there will be a diffrent perception in each person through sense. Perception difference could appear because of diffrent experience from men who had participated 
in vasectomy. In the other side there still a wrong perception about vasectomy such as vasectomy is a frightening medical option $(38,4 \%)$, will causing impotence $(37,2 \%)$, vasectomy is equal thing with emasculated $(31,4 \%)$ and it will be very endanger $(29,1 \%)$.

Another perception from husband, reproductive control program participation could decrease sexual satisfaction, another negative cultures perception this program is only for several men who want to make a relationship without married and some perception from women and family who thinks vasektomy is a expensive procedure. (LDUIPULDU BKKBN, 1998

This study result is different from Budisantoso study in 2009, this result showed husband perception in Bantul
Subdistrict. (Budisantoso, 2009) In suficient category is about $77 \%$ and good category is about $12 \%$ meanwhile low This This study result is different from Budisantoso study in 2009, this result showed husband perception in Bantul Subdistrict. (Budisantoso, 2009) In suficient category is about $77 \%$ and good category is about $12 \%$ meanwhile low category is about $11 \%$. Result of Chi Square test showed there's a significant correlation of perception with husband participation with $\mathrm{p}$-value $=0,007$ $<\alpha=0,005$.

Influence of Belief, Expectation and Perception on Husband Participation in Vasectomy.

Variables which become multivariat variable candidate model are independent variables with $p$-value $<0,25$.

Table 5. Multivariat variable candidate model

\begin{tabular}{|l|l|}
\hline Variables & $\mathrm{p}$-Value \\
\hline Belief & $0,017^{*}$ \\
\hline Expectation & $0,007^{*}$ \\
\hline Perception & 0,464 \\
\hline
\end{tabular}

*= Multivariat candidate

Based on table 5 bivariat analysis, only variables with $p$-Value $<0,25$ could get in next step as multivariat variables. That is belief and expectation. Then these variables got analyzed by regresion logistik test with enter method, which all independent variables are get into model.

Table 6. Regression Logistic Analyze Result

\begin{tabular}{|l|l|l|l|l|}
\hline Variables & B & $\begin{array}{l}\text { Exp } \\
\text { (B) }\end{array}$ & SE & $\begin{array}{l}\text { - } \\
\text { Value }\end{array}$ \\
\hline Belief & 1,153 & 3,167 & 0,769 & 0,134 \\
\hline Expectation & $-1,686$ & 0,185 & 0,661 & 0,011 \\
\hline Constant & $-21,513$ & 0,000 & 13345,120 & 0,999 \\
\hline
\end{tabular}

*-2 Log Likelihood=84,211

$* *$ p-Value $=0,000$ 
Based on table 6, showed significant Log Likelihood $(0,000)<\alpha(0,05)$ it indicate that model are significant. Based on p-Value of each variables only expectation could get into next regression logistic models.

Table 7. Last Regression Logistic Models The inInfluences of Belief, Expectation and Perception on Husband Participation.

\begin{tabular}{|l|l|l|l|l|}
\hline Variable & B & Exp (B) & SE & -Value \\
\hline Expectation & $-1,440$ & 0,237 & 0,501 & 0,004 \\
\hline Constant & 0,405 & 1,500 & 0,408 & 0,321 \\
& & & & \\
*-2 Log Likelihood=103,855 & **p-Value $=0,003$
\end{tabular}

Table 7 showed significant log likelihood $(0,003)<\alpha(0,05)$. It indicates models significant. Multivariat analysis showed p-Value $(0,004)<\alpha(0,05)$ it means expectation have a strong influence on husband participation in vasectomy.

Regression Logistic Models result:

$\log p=0,405-1,440$ (Expectation)

Based on the result, expectation is a strongest influence variables from all variables Expecation from respondent is a strongest influence factor to decide be participant in vasectomy with B-Value-1,440 which mean the smaller B-Value obtained, makes expectation become greater in vasectomy.

\section{CONCLUSION}

The number of husband who had participated in vasectomy are only 31 people (36\%) and husband who did'nt participated in vasectomy are 22 people (64\%). Chi Square test showed belief and expectation had significant correlation with husband participation in vasektomy, but perception had'nt correlation on husband participation in vasectomy Regression logistic test showed expectation from husband is a strongest influences factor from respondent to make decision on vasectomy.

\section{REFERENCES}

Anggraeni. (2007) Peran Suami dalam Penggunaan Alat Kontrasepsi yang Berwawasan Gender. The Soedirman Journal of Nursing, Vol. 2, No. 2 Juli 2007.

BKKBN. (2007). Panduan Pelaksanaan KIP/Konseling Kontrasepsi Pria. Jakarta.

BKKBN. (2008). Kesadaran Akan Pentingnya Kontrasepsi di Indonesia Perlu Ditingkatkan.

http;//gemapria.bkkbn.go.id/articledetail.php?artid=96. Artikel diakses 10 September 2008.

Budisantoso, S. I. 2009. Partisipasi Pria dalam Keluarga Berencana di Kecamatan Jetis Kabupaten Bantul. Jurnal Promosi Kesehatan Indonesia Vol. 4, No. 2.

Data Pemberdayaan Perempuan, Anak dan Keluarga Berencana Deli Serdang. (2011).

Everett, S. (2008). Kontrasepsi dan Kesehatan Seksual Reproduktif. Jilid I, Ed. 1, Bandung, Penerbit Tarsito.

LDUIPULDU BKKBN. (1998). Faktor-faktor Sosial Budaya yang Mempengaruhi 
Pemakaian Kontrasepsi Mantap Pria di Jawa Barat dan NTB.

Pramesti, O. L. (2012). Rendahnya Partisipasi Pria Mengikuti Program KB.

http;//nationalgeographic.co.id/berita /2012/02/rendah-partisipasi-pria.

(Berita Kesehatan) diakses 28

Februari 2012 